\title{
Adult onset motor neuron disease: worldwide mortality, incidence and distribution since 1950
}

\author{
A M Chancellor, C P Warlow
}

\begin{abstract}
This review examines the commonly held premise that, apart from the Western Pacific forms, motor neuron disease (MND), has a uniform worldwide distribution in space and time; the methodological problems in studies of MND incidence; and directions for future epidemiological research. MND is more common in men at all ages. Age-specific incidence rises steeply into the seventh decade but the incidence in the very elderly is uncertain. A rise in mortality from MND over recent decades has been demonstrated wherever this has been examined and may be real rather than due to improved case ascertainment. Comparison of incidence studies in different places is complicated by non-standardised methods of case ascertainment and diagnosis but there appear to be differences between well studied populations. In developed countries in the northern hemisphere there is a weak positive correlation between standardised, age-specific incidence and distance from the equator. There is now strong evidence for an environmental factor as the cause of the Western Pacific forms of MND. A number of clusters of sporadic MND have been reported from developed countries, but no single agent identified as responsible.
\end{abstract}

(F Neurol Neurosurg Psychiatry 1992;55:1106-1115)

The term MND is usually applied to a spectrum of motor system disorders which include both childhood and adult forms. ${ }^{12}$ Recent advances have been made in understanding those forms which have a genetic basis. ${ }^{34}$ Although a number of conditions have been identified which may mimic MND for the vast majority of patients with sporadic adult onset disease the cause is unknown. ${ }^{5-7}$

The possibility that environmental factors play a role in MND, particularly in the light of studies from the Western Pacific, ${ }^{8}$ is an appealing and recurring theme. ${ }^{9}$ This hypothesis, however, is not supported by the traditional teaching that the distribution of MND in developed countries is uniform and static. ${ }^{10-14}$ A recent editorial ${ }^{15}$ has challenged this view, suggesting that the distribution of MND in time and place may not be as uniform as previously believed. The tendency of many epidemiological reports to reiterate principles expounded in the 1950s may reflect methodological or statistical difficulties in detecting true differences in the distribution of the disease within and between countries, and at different times. Clearly non-random distributions are important to identify as clues to potential environmental risks.

It has been ten years since the last review of the epidemiology of $\mathrm{MND}^{14 \star}$ and since then important additional observations have been made. A thorough reappraisal of the subject seems timely. Our aims are therefore to: 1) review all publications concerned with the mortality and incidence of adult onset MND in defined populations. Publications were specifically reviewed for any evidence of a nonrandom distribution in place both between studies and within populations. Some incidence studies also calculate, or include, a prevalence survey but studies exclusively of MND prevalence are not incorporated in this analysis as they do not add further to aetiological considerations; 2) review secular trends in this disease; 3) examine the reports of clusters of MND which might provide clues to environmental influences; 4) compare the epidemiology of the Western Pacific forms with sporadic MND, and summarise the results of the intensive search for its cause; 5) identify standards for future epidemiological studies of MND and possible research directions.

\section{Methods}

This paper was prepared according to recent guidelines for medical reviews. ${ }^{1617} \mathrm{~A}$ comprehensive search by individual year using Cambridge Compact Disc Medline from January 1965-June 1991 was used to identify all publications in English, or with English abstracts, dealing with the frequency (mortality or incidence) of adult onset MND in defined populations worldwide. The references in these publications were used to cross-check the thoroughness of this search and to locate papers published from 1950-65. In addition any papers dealing with survival or prognosis, which may contain incidence data and reports of clusters, were specifically sought. All papers were reviewed in the original.

Many population-based studies of MND have been published which vary widely in their quality. For the purposes of systematic analysis these were divided into mortality studies, based only on death certificate data, ${ }^{18-32}$ and incidence studies divided according to their methodology. Valid comparisons between studies can only be made if similar methodological 
Table 1a Studies of adult onset MND based only on mortality (death certificate) data

\begin{tabular}{|c|c|c|c|c|}
\hline Location & $\operatorname{Year}(s)$ & $\begin{array}{l}\text { Range of mortality } \\
\text { over study period } \\
\text { (crude rate/100,000) }\end{array}$ & Notes & Reference \\
\hline Japan & $1952-71$ & $0.4-0.6$ & $\begin{array}{l}\text { Rising rate from } 1952 \text { and then a fall after } \\
1960 \text {. Includes worldwide mortality data } \\
\text { 1954-1971 compared with Parkinson's disease } \\
\text { which did not change }\end{array}$ & 19 \\
\hline England/Wales & 1959-1986 & $1 \cdot 2-1 \cdot 6$ & $\begin{array}{l}\text { Increasing mortality over study period. } \\
\text { Standardised mortality ratio } 79 \text { in } 1968,129 \text { in } \\
\text { 1986. Non random distribution in place }\end{array}$ & 20,21 \\
\hline Sweden & $1961-85$ & $1 \cdot 0-2 \cdot 5$ & $\begin{array}{l}\text { Figures divided into ALS and MND as a whole. } \\
\text { Rise greater for ALS. Age standardised rate } \\
\text { doubled over study period. }\end{array}$ & 22 \\
\hline United States & $1962-84$ & $\begin{array}{l}\text { age/sex specific rates } \\
\text { only }\end{array}$ & $\begin{array}{l}\text { Rising rates, with substantial changes } \\
\text { particularly amongst the elderly }\end{array}$ & $23-25$ \\
\hline Finland & $1963-72$ & 0.9 & $\begin{array}{l}\text { More common in women }(0 \cdot 87: 1) \text {. Clustering } \\
\text { in south east }\end{array}$ & 26 \\
\hline $\begin{array}{l}\text { France } \\
\text { United States } \\
\text { Scotland } \\
\text { Norway }\end{array}$ & $\begin{array}{l}1968-82 \\
1968-78 \\
1968-87 \\
1969-85\end{array}$ & $\begin{array}{l}0 \cdot 7-1 \cdot 5 \\
0 \cdot 9 \\
1 \cdot 2-2 \cdot 1 \\
1 \cdot 6-2 \cdot 8(\mathrm{~m}) \\
1 \cdot 2-1 \cdot 8(\mathrm{f})\end{array}$ & $\begin{array}{l}\text { Steadily increasing rate especially for }>55 \text { years } \\
\text { Highest rates west of Mississippi } \\
\text { Significant rise with time. } \\
\text { Substantial rises especially in men and elderly }\end{array}$ & $\begin{array}{l}27 \\
28 \\
\star \\
29\end{array}$ \\
\hline
\end{tabular}

Notes: Listed in ascending order of first year of data collection. Studies of individual USA states ${ }^{30}{ }^{32}$ not included. For the

USA and England and Wales notes incorporate more than one study. ${ }^{\star} R$ J Swingler, personal communication

standards and diagnostic criteria are applied. While most epidemiological studies included the syndromes of amyotrophic lateral sclerosis (ALS), restricted progressive bulbar palsy (PBP) and progressive muscular atrophy (PMA), some studies were confined to ALS. The best incidence studies used multiple sources of case ascertainment, and/or were based on recognised systematic medical documentation systems. ${ }^{33-43}$ The second group of incidence studies were based on more than just tertiary referral records but there was some doubt about the completeness of case finding. ${ }^{44-53}$ The third group were those in which incidence had been based, principally or exclusively on neurological centres, or where data were incomplete in review, or where the diagnosis was based on unverified hospital discharge statistics. ${ }^{54-63}$ There are a large number of clinical series of patients with MND but these were not analysed if a population denominator was unclear or unspecified. ${ }^{6465}$

\section{Results}

Mortality studies (tables $1 a, b$ )

According to the rules for selection of cause of death for primary mortality tabulation by the World Health Organisation, MND should be coded as the underlying cause even if it appears as a contributing factor. ${ }^{19}$ This may, however, not be followed in standard practice and some studies have used rates for MND classified as

Table 1b. A comparison of age-specific mortality rates per 100,000 between countries from table la from which this information can be derived.

\begin{tabular}{|c|c|c|c|c|c|c|}
\hline & \multicolumn{6}{|c|}{ Country } \\
\hline & \multicolumn{2}{|c|}{ England and Wales ${ }^{20}$} & \multicolumn{2}{|c|}{ United States $^{24}$} & \multicolumn{2}{|c|}{ Finland $^{27}$} \\
\hline & Male & Female & Male & Female & Male & Female \\
\hline \multirow[t]{2}{*}{$\begin{array}{l}\text { Age Band } \\
60-64 \text { years } \\
65-69 \text { years } \\
70-74 \text { years }\end{array}$} & $\begin{array}{l}\text { Age ar } \\
5 \cdot 8 \\
7 \cdot 7 \\
8 \cdot 5\end{array}$ & $\begin{array}{l}\text { specific } \\
4 \cdot 6 \\
5 \cdot 5 \\
5 \cdot 8\end{array}$ & $\begin{array}{l}4 \cdot 9 \\
6 \cdot 1 \\
7 \cdot 6\end{array}$ & $\begin{array}{l}3 \cdot 5 \\
4 \cdot 1 \\
4 \cdot 7\end{array}$ & $\begin{array}{l}4 \cdot 5 \\
6 \cdot 0 \\
2 \cdot 8\end{array}$ & $\begin{array}{l}3.5 \\
6.1 \\
3.5\end{array}$ \\
\hline & \multicolumn{6}{|c|}{ 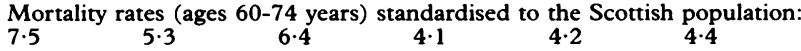 } \\
\hline
\end{tabular}

the "underlying cause" and excluded patients with MND whose deaths were certified as due to another cause ${ }^{20}$ while others have separated the two groups ${ }^{25}$ or used rates based on wherever the diagnosis appears on the death certificate. $^{26}$ Comparison of rates for subgroups of MND (that is, ALS, PBP, PMA) based on death certificate data are complicated by changes in the International Classification of Diseases (ICD) and non-standardised methods of diagnosis. ICD-9, introduced in 1979, was a further change from ICD-8 with respect to MND. ${ }^{14}$ ALS had previously been recorded as a distinct entity (code 348.0, ICD8 ), although some studies use ALS to refer to all types of $\mathrm{MND}^{27}$ In ICD-9 a new code, ICD-335, was created for all anterior horn cell diseases with 335.2 for "motor neurone disease", which contains "ALS; MND (bulbar) (mixed type), and PMA (pure)". A further ICD is planned for 1993. Death certificate data alone are therefore unlikely to be reliable enough for comparing rates of MND subgroups or even for comparing rates between different countries, particularly when these overlap ICD changes, and because of the confusion which exists over diagnostic criteria (see below). They may be adequate for following trends in total MND rates within countries.

Age specific mortality rates, where given, usually rise to a peak between 60 and 75 years, followed by a sharp decline, but this may simply reflect difficulties with diagnosis in the very elderly. In Sweden, for some birth cohorts followed up separately over time, the mortality increased continuously with age. ${ }^{22}$ Rates in males are consistently higher than in females, usually by about $1 \cdot 5: 1$.

When international mortality figures were last reviewed in detail, ${ }^{19}$ a rise from 1952-60 followed by a sharp fall until 1971 was observed in Japan while in contrast, a rise in European and Australasian rates and stationary figures for the USA were noted. There is more recent evidence from the $\mathrm{UK}^{20}{ }^{20}$ Sweden, ${ }^{22}$ USA, ${ }^{2324}$ France, ${ }^{26}$ Norway ${ }^{29}$ and most recently, Scotland (R.J. Swingler, personal 
Table $2 a$ Retrospective incidence studies of adult onset MND most likely to have complete or near complete case ascertainment

\begin{tabular}{|c|c|c|c|c|c|c|c|c|c|c|c|}
\hline Location & Years & Methods & $A L S$ & $P B P$ & $P M A$ & $\begin{array}{l}\text { Population } \\
\text { (millions) }\end{array}$ & $\begin{array}{l}\text { Cases } \\
(n)\end{array}$ & $\begin{array}{l}\text { Incidence } \\
\text { Crude/100 000/yr } \\
(95 \% \text { CI) }\end{array}$ & $\begin{array}{l}\text { Prevalence } \\
1100000\end{array}$ & Notes & Reference \\
\hline $\begin{array}{l}\text { Rochester, } \\
\text { USA }\end{array}$ & $1925-84$ & $\begin{array}{l}\text { Mayo clinic computerised } \\
\text { diagnostic index of } \\
\text { Rochester residents }\end{array}$ & $\mathbf{Y}$ & $\mathbf{Y}$ & $\mathbf{N}$ & 0.36 & 44 & $2 \cdot 0(1 \cdot 4-2 \cdot 7)$ & & $\begin{array}{l}\text { Updated previous study } \\
(1925-77) \text {, small but non } \\
\text { significant increase in } \\
\text { incidence }\end{array}$ & 33,34 \\
\hline Israel & 1959-74 & $\begin{array}{l}\text { National neurological } \\
\text { disease register }\end{array}$ & $\mathbf{Y}$ & $\mathbf{Y}$ & $\mathbf{Y}$ & $21 \cdot 8$ & 246 & $0.7(0.6-0.8)$ & & $\begin{array}{l}\text { Increasing incidence in } \\
>60 \mathrm{yrs}\end{array}$ & 35,36 \\
\hline Sardinia, Italy & $1965-74$ & $\begin{array}{l}\text { Hospital archives, } \\
\text { national statistics, } \\
\text { neurology departments, } \\
\text { General practioners }\end{array}$ & $\mathbf{Y}$ & $\mathbf{N}$ & $\mathbf{N}$ & $1 \cdot 49$ & 96 & $0.6(0.5-0.7)$ & 1.5 & $\begin{array}{l}\text { Uniform distribution. } \\
\text { Rates higher in } \\
\text { agricultural workers. } \\
\text { Young mean age of onset } \\
\text { (56 years) }\end{array}$ & 37 \\
\hline North Sweden & $1969-80$ & $\begin{array}{l}\text { Neurology department, } \\
\text { questionnaire to others, } \\
\text { Death certificates }\end{array}$ & $\mathrm{Y}$ & $\mathbf{N}$ & $\mathbf{N}$ & 0.65 & 128 & $1 \cdot 7(1 \cdot 4-2 \cdot 0)$ & $4 \cdot 8$ & $\begin{array}{l}\text { No significant clusters } \\
\text { Male to female ratio } 1 \cdot 1: 1\end{array}$ & 38 \\
\hline $\begin{array}{l}\text { Varmland } \\
\text { county, } \\
\text { Sweden }\end{array}$ & $1970-81$ & $\begin{array}{l}\text { Inquiry to clinics of } \\
\text { medicine, geriatrics, } \\
\text { death certificates }\end{array}$ & $\mathbf{Y}$ & $?$ & $\mathbf{Y}$ & 0.28 & 89 & $2 \cdot 6(2 \cdot 1-3 \cdot 2)$ & $8 \cdot 5$ & $\begin{array}{l}\text { Higher rate }(p<\cdot 01) \text { in } \\
\text { this county than } \\
\text { remainder of Sweden }\end{array}$ & 39 \\
\hline Denmark & $1974-86$ & $\begin{array}{l}\text { Computerised hospital } \\
\text { data base for } 2 \text { counties }\end{array}$ & $\mathbf{Y}$ & $\mathbf{Y}$ & $\mathbf{N}$ & 1.05 & 186 & $1.4(1.2-1.6)$ & $3 \cdot 1$ & $\begin{array}{l}\text { Female preponderance in } \\
\text { patients }>60 \mathrm{yrs} \text { with } \\
\text { bulbar onset }\end{array}$ & 40 \\
\hline $\begin{array}{l}\text { Middle } \\
\text { Finland }\end{array}$ & $1976-81$ & $\begin{array}{l}\text { Hospital discharge data, } \\
\text { death certificates }\end{array}$ & $\mathbf{Y}$ & $\mathbf{N}$ & $\mathbf{N}$ & 0.24 & 36 & $2 \cdot 4(1 \cdot 7-3 \cdot 3)$ & $6 \cdot 4$ & $\begin{array}{l}\text { Incorporates a case } \\
\text { control study }\end{array}$ & 41 \\
\hline NW England & $1976-86$ & $\begin{array}{l}\text { Neurology department, } \\
\text { hospital discharge data }\end{array}$ & $\mathbf{Y}$ & $\mathrm{Y}$ & $\mathbf{Y}$ & $1 \cdot 84$ & 173 & $1.9(1 \cdot 6-2 \cdot 2)$ & & $\begin{array}{l}\text { Small area analysis shows } \\
\text { clusters but this may be } \\
\text { due to chance }\end{array}$ & 42 \\
\hline $\begin{array}{l}\text { SW Ontario, } \\
\text { Canada }\end{array}$ & $1978-82$ & $\begin{array}{l}\text { Hospital notes, ALS } \\
\text { society case register, } \\
\text { Death certificates }\end{array}$ & $\mathrm{Y}$ & $\mathrm{Y}$ & $\mathbf{Y}$ & 1.71 & 139 & $1.6(1.3-1.9)$ & $4 \cdot 9$ & $\begin{array}{l}\text { Uneven distribution } \\
\text { between counties (non } \\
\text { significant) }\end{array}$ & 43 \\
\hline
\end{tabular}

Notes: Studies listed in ascending order of first year of data collection. $\mathrm{Y}=$ Yes; $\mathrm{N}=\mathrm{No}$; ALS = amyotrophic lateral sclerosis; PBP = progressive bulbar palsy; $\mathrm{PMA}=$ progressive muscular atrophy; NW = north west; $\mathrm{SW}=$ south west.

communication) that mortality rates are continuing to rise with time (table 1a). In the USA overall ALS mortality increased $46 \%$ for men and $49 \%$ for women between 1977-86; the greatest increases in age specific mortality have occurred in the older age groups ${ }^{24}$ but increases are also apparent in middle age groups. ${ }^{23}$ The question arises if this trend is artefactual, a result of improvement in diagnostic accuracy and increased case ascertainment (particularly in the elderly where age-specific rates are high), or due to changes in ICD coding. However, mortality from MND does not correlate with the number of neurologists in the $\mathrm{UK}^{20}$ or the physician/population ratio in the USA; ${ }^{28}$ there has been much less of a parallel increase in the number of neurologists in the UK than USA; technological advances such as nuclear magnetic resonance imaging (MRI) and the identification of syndromes which mimic MND are likely to reduce, rather than inflate rates and the disease is distinctive and of such high lethality that significant changes in reporting seem unlikely.

The interpretation of variation in mortality with place is complicated by changes over time, the use of different age bands for age specific rates and variable methods in the extraction of death certificate information. A comparison of standardised mortality rates for the age bands between 60 and 74 years (where random error and diagnostic bias are minimised) is presented in table $1 \mathrm{~b}$; these data are extracted from those published mortality studies in table 1 a for which this was possible. Higher rates are observed in the UK compared with Finland and the USA.

Whether the incidence of MND can be studied adequately on the basis of mortality data alone is uncertain. ${ }^{25}$ Although $70-90 \%$ of patients diagnosed with MND have this recorded on their death certificate, ${ }^{19206667}$ only one study from Japan has examined the false positive rate of death certificate coding (in 1965) by an extensive attempt to verify the diagnosis from other sources. As many as one third of males were coded as dying of MND without having it, but the accuracy was better for females. ${ }^{19}$

Incidence studies (table $2 a, b$ )

1) Crude rates

The best incidence studies are presented in table 2a together with the methods, crude

Table $2 b$. A comparison of age and sex specific incidence and age standardised incidence, 45-74 years, by country

\begin{tabular}{|c|c|c|c|c|c|c|c|c|}
\hline & \multicolumn{8}{|l|}{ Country } \\
\hline & $\begin{array}{l}\text { Rochester } \\
\text { Male/Female }\end{array}$ & $\begin{array}{l}\text { Israel }^{*} \\
\text { Male/Female }\end{array}$ & $\begin{array}{l}\text { Sardinia } \\
\text { Male/Female }\end{array}$ & $\begin{array}{l}\text { Sweden } 1 \\
\text { Male/Female }\end{array}$ & $\begin{array}{l}\text { Sweden } 2 \\
\text { Male/Female }\end{array}$ & $\begin{array}{l}\text { Denmark } \\
\text { Male/Female }\end{array}$ & $\begin{array}{l}\text { Finland } \\
\text { Male/Female }\end{array}$ & $\begin{array}{l}\text { Canada } \\
\text { Male/Female }\end{array}$ \\
\hline \multirow{4}{*}{$\begin{array}{l}\text { Age band } \\
\text { years } \\
45-54 \\
55-64 \\
65-74\end{array}$} & \multicolumn{8}{|c|}{ Age specific rate } \\
\hline & $\begin{array}{l}2 \cdot 0 / 2 \cdot 6 \\
9 \cdot 5 / 5 \cdot 2 \\
13 \cdot 2 / 12 \cdot 6\end{array}$ & $\begin{array}{l}2 \cdot 1 / 1 \cdot 2 \\
3 \cdot 3 / 1 \cdot 8 \\
2 \cdot 9 / 1 \cdot 4\end{array}$ & $\begin{array}{l}2 \cdot 2 / 0 \cdot 9 \\
3 \cdot 2 / 1 \cdot 8 \\
6 \cdot 6 / 1 \cdot 5\end{array}$ & $\begin{array}{l}1 \cdot 0 / 1 \cdot 0 \\
7 \cdot 8 / 4 \cdot 2 \\
10 \cdot 0 / 5 \cdot 8\end{array}$ & $\begin{array}{l}5 \cdot 9 / 3 \cdot 2 \\
9 \cdot 0 / 4 \cdot 2 \\
12 \cdot 3 / 6 \cdot 5\end{array}$ & $\begin{array}{l}2 \cdot 1 / 0 \cdot 8 \\
5 \cdot 2 / 3 \cdot 5 \\
6 \cdot 2 / 5 \cdot 0\end{array}$ & $\begin{array}{l}4 \cdot 6 / 5 \cdot 1 \\
10 \cdot 3 / 11 \cdot 8 \\
13 \cdot 7 / 8 \cdot 4\end{array}$ & $\begin{array}{l}3 \cdot 0 / 2 \cdot 0 \\
5 \cdot 5 / 4 \cdot 0 \\
9 \cdot 0 / 5 \cdot 5\end{array}$ \\
\hline & \multirow{2}{*}{\multicolumn{8}{|c|}{$\begin{array}{l}\text { Incidence age standardised to the Scottish population (age 45-74 years only): } \\
7 \cdot 5 / 6 \cdot 5 \\
2 \cdot 7 / 1 \cdot 5\end{array}$}} \\
\hline & & & & & & $4 \cdot 2 / 3 \cdot 0$ & $9 \cdot 0 / 8 \cdot 4$ & $5 \cdot 4 / 3 \cdot 7$ \\
\hline
\end{tabular}

Notes: See also table 2a (age specific rates not given for NW England study). Rates $/ 100$ 000/year.

In some studies age specific rates are extrapolated from graphed values because of differing age bands employed.

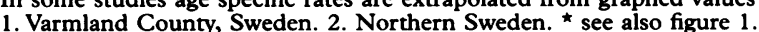


Table 3 Syndromes which may mimic idiopathic MND

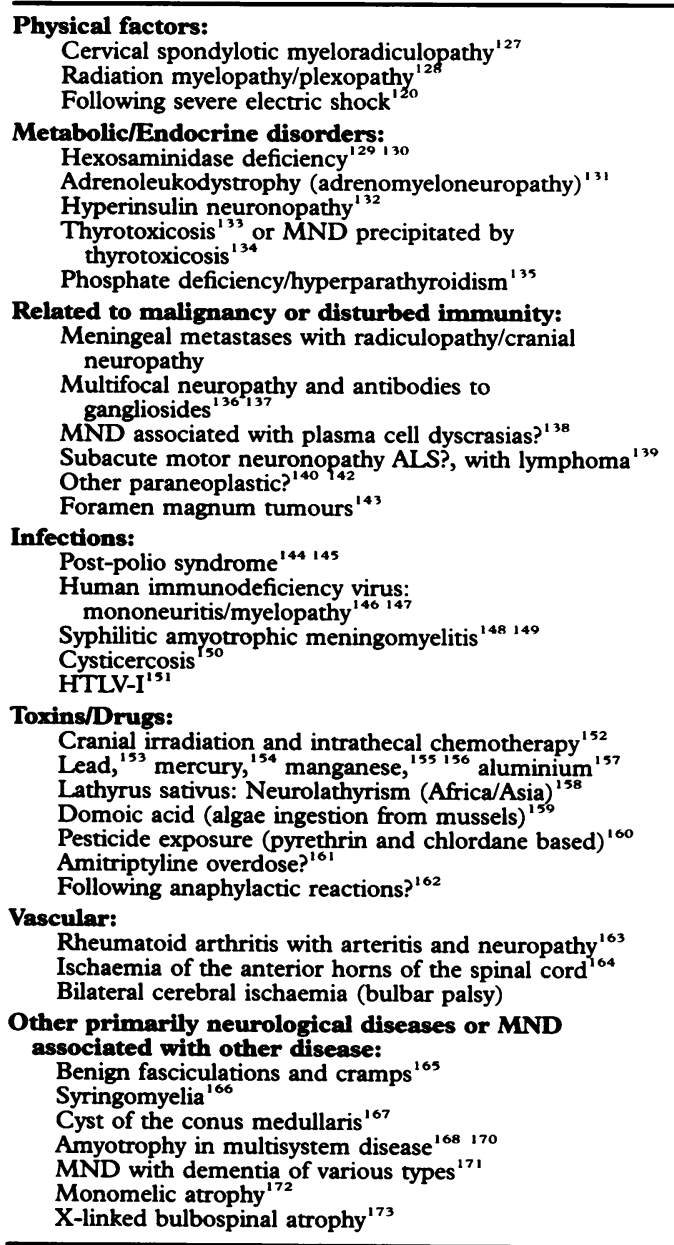

Note: A differential diagnosis of the idiopathic anterior horn cell disorders is not included.

incidence with calculated $95 \%$ confidence intervals, ${ }^{68}$ prevalence rates (where stated) and notes. Although crude incidence may differ between populations because of differences in age structure, when the studies were divided according to the quality of their methodology, in general, the crude rates tended to reflect the likely degree of case ascertainment. There was a significant difference between the mean crude rate of those studies in table $2 \mathrm{a}$ compared with all other studies (difference = $0 \cdot 64 / 100000 /$ year $95 \%$ CI $0 \cdot 15-1 \cdot 13$ ) and when studies in table $2 \mathrm{a}$ were compared with those which relied on single hospital case ascertainment (difference $=0.75 / 100000 /$ year, $95 \%$ CI $0 \cdot 21-1 \cdot 3$ ). However, there were exceptions; for example, a low crude rate was seen in Israel, ${ }^{36}$ based on a comprehensive survey of Jews as part of a national neurological disease register, and in Sardinia, ${ }^{37}$ which used five separate sources of case finding. The claim of a low incidence in Mexico ${ }^{46}$ was based on individuals with access to a government health programme and while medical facilities may have been excellent for those with access, it is not certain that all affected individuals with MND were identified. A lower mortality in Mexico than any other of 33 countries, including others in the developing third world, was observed in a large comparative analysis of average age adjusted rates, at least around $1950 .^{18}$ If this observation is not artefactual then it may be evidence of an ethnic "resistance", or a result of environmental factors.

2) Age and sex specific incidence rates, standardised rates

Age and sex specific rates in all incidence studies, except Rochester, ${ }^{34}$ show a steady rise to a peak, usually between 60 and 75 years with a sharp decline after this (fig 1). In Rochester the rate appears to continue to rise with age, although the numbers are small and confidence intervals for the older age groups are so wide that a decline cannot be excluded. This is of considerable interest from an aetiological viewpoint; if a true decline occurs in the elderly then the disease is perhaps more likely to reflect an environmental influence rather than simply a result of age related neuronal attrition. The majority of reports show a male predominance with a range between $1 \cdot 2: 1$ to $2 \cdot 0: 1$, but some show no sex difference ${ }^{45}$ or even a female predominance. ${ }^{27}$ Incidence rates with time, although reported as increasing, are unreliable in studies with small numbers. ${ }^{34}$ In Israel this increase was considered to be due to causes other than improved case ascertainment. ${ }^{35}$

Meaningful direct, statistical comparisons of age and sex specific rates between studies are complicated by methodological differences, the use of different age bands and because overlap with the same years of study are necessary to minimise possible differences due to changing incidence over time. The age specific rates for males and females combined from three of the best incidence studies ${ }^{3435} 40$ are plotted in the figure to demonstrate the range. It can be seen that there are differences in incidence between the studies from Rochester and Israel and the $95 \%$ confidence intervals for these two studies (not shown) suggest the difference is real. When the rates for the age bands 45-74 years (likely to be the most reliable for comparative purposes) for males and females are standardised to the Scottish population (table $2 \mathrm{~b}$ ), the differences between populations are also apparent. When age stan-

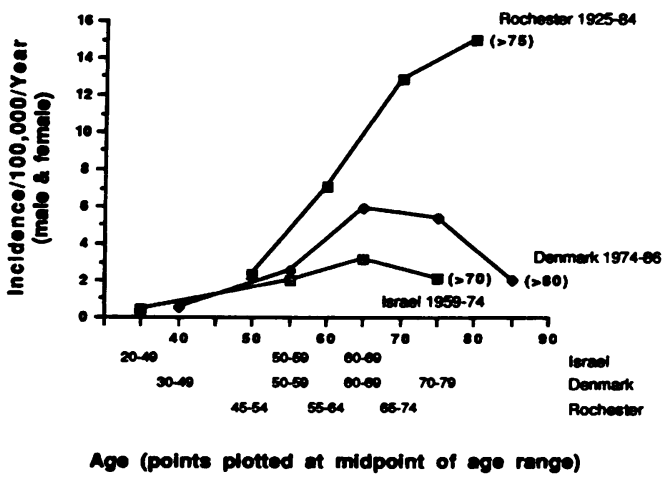

Figure 1 Age specific incidence of adult onset MND (male and female) in three countries selected from table $2 a$ to show the range. 


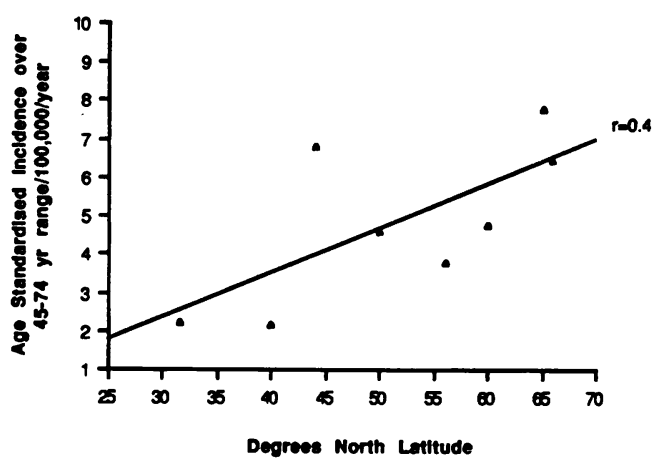

Figure 2 Correlation of age standardised incidence of $M N D$ with mean degrees north latitude (studies from table 2b).

dardised rates (over 45-74 years) for males and females combined from those studies in table $2 a$ (excluding NW England where insufficient data for this calculation are provided) are plotted against their degrees north latitude (fig 2 ), there is a positive correlation ( $p$ value for the slope 0.05 ). The cause of this relationship is uncertain.

\section{3) Clusters}

There are reports of conjugal ${ }^{6970}$ and other nonconsanguineous clusters of MND outside the Western Pacific, with rates much higher than would be expected by chance. Examples include people who work ${ }^{7172}$ or live ${ }^{73-75}$ in close proximity; play in the same sports team; ${ }^{76}$ have been war evacuees; ${ }^{77}$ share an environmental peculiarity such as high soil selenium; ${ }^{78}$ or a common occupational exposure such as leather $^{79}$ or textile ${ }^{80}$ workers. Toxins from freshly caught fish were implicated in a cluster in Wisconsin. ${ }^{81}$ In one example, ${ }^{74}$ all those affected were of Ashkenazi Jewish extraction. It is not clear if the high incidence in Filipino men in Hawaii is because of a genetically susceptible pool with a high predisposition to develop MND or whether other factors are responsible. ${ }^{4482}$ Other studies show a significant $^{83}$ or non-significant ${ }^{20272843}$ uneven distribution but most studies that have examined distribution within a population have demonstrated geographical uniformity. It may be difficult to know whether small clusters are purely due to chance, particularly when the overall population incidence is not known. ${ }^{84} \mathrm{~A}$ recent publication from north west England ${ }^{42}$ attempted to provide further data in this regard by analysing the distribution of 173 cases according to postal areas and allocated through a grid reference to 338 electoral wards. Several wards had a significantly higher than expected rate but, as the authors point out, the actual number of wards showing this non random distribution may not have been greater than the expected normal variation.

One intriguing attempt to demonstrate clustering of MND in relation to an infectious aetiology has examined the correlations between infectious disease notification rates in 1931-39 with mortality from MND in
1968-78. There was a specific positive correlation for poliomyelitis but not for other infectious diseases; nor did poliomyelitis correlate with other leading causes of death. ${ }^{85}$ The suggestion has been made that the rising rate of poliomyelitis during the early decades of this century accounts for the present increasing trend in MND mortality (due to subclinical infection). There is, however, no such correlation in Scotland and little support for viral infection from laboratory studies. ${ }^{86}$ Although late neurological deterioration after poliomyelitis may resemble $M N D,{ }^{87}$ the relationship between previous poliomyelitis and sporadic MND remains a matter of debate. Table 3 gives a list of other syndromes which may mimic idiopathic MND.

\section{4) Western Pacific forms of MND}

The Western Pacific clusters are found in: 1) Guam, the southernmost and largest of the Mariana islands, where the Chamorro Indians are affected; ${ }^{88-90}$ 2) the $\mathrm{Kii}$ peninsula of Japan $^{14}$ and 3) the Auyu and Jakai people of West New Guinea. ${ }^{91}$ In Guam, the most extensively studied of these endemic variates, the clinical features resemble sporadic $\mathrm{MND}$ / ALS, but in the same population there is also a high incidence of a Parkinsonism/dementia complex. The pathology of both these Guamanian diseases includes extensive neurofibrillary tangles in the cerebrum and brainstem of most patients, and in the spinal cord of a minority, as well as anterior horn cell loss ${ }^{92} 93$ in MND/ALS. This difference suggests that the sporadic and Western Pacific forms of MND may have a different aetiology. Discovery of the cause of these high incidence foci might have widespread repercussions for the understanding of sporadic MND.

The evidence for an environmental cause, or at least a genetically determined host response to an exogenous factor, ${ }^{8294-96}$ is now very strong. The disease is confined to a particular area of the Mariana islands despite a shared original migration pattern; ${ }^{97}$ there is no evidence for Mendelian inheritance ${ }^{94}$ and the disease is of no higher incidence in offspring of affected than non affected Guamanians. The incidence of MND/ALS on Guam has declined by at least $50 \%$ from rates that were 50-100 times greater than developed countries in 1950-69 98-101 $^{2}$ although the accuracy of some reports has recently been questioned. ${ }^{102}$ Age of onset may be increasing. ${ }^{93}$ MND does not develop among those who have had a brief exposure to the implicated environment ${ }^{103}$ and the latency for the development of $M N D$, as judged by studies of Chamorro migrants to the USA, is long ${ }^{104} 105$ implying that an early exposure may be crucial, or any proposed environmental factor must be slow acting, or the ageing factor is interacting with an earlier environmental agent. Attempts to transmit the disease have failed. ${ }^{106}$

The putative environmental cause is unknown. If the incidence is declining then this coincides with adoption of a lifestyle closer to Western standards and suggests that environmental factors associated with a primitive 
lifestyle may be important. Neurotoxins in the seeds of the nut Cycad Circinalis (false sago palm), and used by the natives of Guam for the production of flour, are thought by some to be responsible. ${ }^{107} \mathrm{~A}$ degenerative motor system disease with similarities to MND has been produced in primates by feeding the cycad derived toxin-BMAA ( $a$-amino- $\beta$-methylaminoproprionic acid) ${ }^{108}{ }^{109}$ but motor neuron pathology can also be induced by other experimental methods. ${ }^{110}$ Doses required for these experiments are high but washing the seeds, as is the custom, removes all but minute traces of BMAA, ${ }^{11}$ probably to such low levels that toxicity is unlikely. ${ }^{112}$ Gadjusek and others suggest an alternative mechanism. ${ }^{102113114} \mathrm{In}$ New Guinea low concentrations of calcium and magnesium and high levels of aluminium, silicon, titanium, chromium, iron and manganese are present in the well and spring water of those villages in which MND is found and not in those which lie on the major large rivers which originate in the central highlands. The biochemical abnormalities in the water or diet in Guam are less certain but intraneuronal deposits of calcium and aluminium suggest that basic defects in mineral metabolism might impair transport of neurofilament proteins, leading to neurofibrillary tangle formation. ${ }^{115}$ The interested reader is referred elsewhere for details of this extensive debate. ${ }^{116}$

\section{Conclusions}

Mortality statistics in MND may be sufficient for studying trends with time, and possibly variation in place, but are likely to underestimate rates in the elderly, particularly in medically deprived areas, where age-specific rates may be higher than reported. Death certificate data are subject to changes in coding practice and there is little information on the frequency of false positive coding. Nonetheless recent studies of mortality do show a rising trend with time, particularly in older age groups. This is a consistent finding in a number of countries, and it may be real rather than due to ascertainment bias but, if so, its cause is uncertain. If rates really are increasing, then this complicates comparisons between studies in different places conducted over different periods.

There are certainly variations in reported incidence rates in place, most of which can be explained on the basis of differences in case ascertainment with higher rates tending to be from more complete studies. There may, however, be real differences of two to four fold between well studied populations in developed countries, suggesting a non random distribution of MND. The evidence for an environmental factor in the aetiology of the Western Pacific forms is now very strong. The precise factors responsible are unknown but may, if discovered, have important implications for research into the cause of sporadic MND. Areas of interest for future epidemiological research include studies of MND incidence in racial minorities in developed countries; the development of sensitive methods for studying the distribution of MND within populations, such as the computer assisted geographical mapping techniques by grid reference; ${ }^{42}$ prospectively designed studies; and attention to life events and environmental exposures which may be remote from the development of MND.

\section{Criteria for the ideal MND incidence study}

From this review we believe the standards for studies of MND incidence should be:

Standardised diagnostic criteria: The reader must be able to understand clearly what is meant by MND. There are no universally accepted criteria for the diagnosis and there is lack of agreement between neurologists in different countries presented with the same case summaries, particularly when the disease is clinically less fully developed, but pathologically proven. ${ }^{117}$ The terms used by authors under the rubric of MND often vary in their meaning. ALS, PBP and PMA, the usually accepted principal clinical subtypes in adults, are almost certainly varieties of a single disease with the common pathological feature of anterior horn cell loss and variable pyramidal tract involvement. The distribution of pathological changes does not necessarily correlate with clinical features even in well studied cases. ${ }^{18119}$ Some authors even separate MND and ALS as different disorders. ${ }^{120}$ There is increasing evidence, with the widespread use of MRI, that primary lateral sclerosis (PLS), a numerically small group, and much debated entity, is part of the spectrum of MND but with exclusively upper motor neuron signs. ${ }^{121122}$ The term ALS, favoured in North America, generally refers to MND with upper and lower motor neuron signs with or without bulbar features, although ALS literally implies disease caused by sclerosis of spinal lateral tracts and anterior horns. A practical consensus statement for clinical and epidemiological studies is required which deals with the problems of defining the clinical limits of $M N D$, reducing interobserver error in the interpretation of physical signs (for example when is a retained reflex in a wasted corresponding myotome an upper motor neuron sign?) and to define the subgroups of MND which may have a different prognosis. A subcommittee of the World Federation of Neurology has recently drafted proposals for a system of classification of ALS, but this is so extraordinarily complex, and dependent on detailed electrophysiological evaluation, that it is quite unsuitable for application in large scale epidemiological studies. In brief, we believe definite cases should exhibit a combination of lower motor neuron signs (clinically or by electromyography), and upper motor neuron signs, not due to longstanding neurological disease, which involve the brainstem and one or more spinal regions (cervical, thoracic, lumbosacral). In addition there should be a progressively deteriorating course and no abnormal sensory signs (including visual abnormalities); sphincteric disturbance; Parkinsonism; dementia and causes of MND mimic syndromes which might be confused with idiopathic disease (table 3). Bulbar 
involvement removes the possibility of multiple level spinal spondylotic disease, the most commonly confused entity. Probable MND (spinal ALS, PBP, PMA and PLS) should be included in the calculation of incidence but defined separately.

\section{Complete case ascertainment}

A study design ensuring complete case ascertainment is of overwhelming importance when studying variation of incidence in time and place, seeking putative environmental factors, or when studying prognosis. In developed countries most patients are likely to have attended regional neurological services but complete case ascertainment cannot be guaranteed by studies which rely exclusively on data from such sources. In particular, we agree with others ${ }^{123}$ that studies from specialised centres $^{124125}$ are likely to be biased in favour of younger patients. The elderly, in whom age specific rates are high, but the diagnosis may be more difficult, are particularly likely to be missed without searches using multiple sources of case ascertainment. However, special care is required in the elderly as the diagnosis may be particularly difficult due to frailty, coexisting disease, or death from other causes before the passage of time has clarified the diagnosis. Multiple sources of case ascertainment should include neurologists, hospital discharge data; primary care physicians and death certificate monitoring. Patient organisations or family care workers may provide useful information but cannot be used as the sole source as this is likely to lead to an underestimate of the true incidence and contamination by other diseases.

Well defined denominator and standard presentation of rates by age, sex and race

Accurate demographic information of the population at risk must be available so that appropriate denominators can be used. This may be a problem in developing countries. Misleading rates for an open ended upper age band may be the result of changes in population age structure rather than true changes in disease incidence. Information should therefore be provided in five year age bands for the total population to allow comparison over time and between studies for a given age band, or combination of age bands.

Prospective design and large population base Retrospective studies allow the passage of time to clarify diagnostic problems but are disadvantaged in other ways. Prospective data collection allows the application of standardised diagnostic criteria including electrodiagnostic tests. The low incidence of MND means such studies require a large population base and hence wide collaboration and rigorous case monitoring and follow up.

No incidence studies are available which fulfil all these criteria although we are now attempting such a study in Scotland. ${ }^{126}$

* A further review has been published since the preparation of this manuscript (Kurtze JF. Risk factors in amyotrophic lateral sclerosis. Adv Neurol 1991;56:245-70).
A M Chancellor was supported by a grant from the Scottish Motor Neurone Disease Association.

1 Walton J, Thomas PK. World Federation of Neurology Committee Research Group on Neuromuscular Diseases. $\mathcal{f}$ Neurol Sci 1988;86:333-60.

2 Tandan R. Disorders of the upper and lower motor neurons. In: Bradley WG, Daroff RB, Fenichel GM, Marsden C, eds. Neurology in clinical practice. Butterworth-Heinemann, 1990:1687-717.

3 Conneally PM. A first step toward a molecular genetic analysis of amyotrophic lateral sclerosis. $N$ Engl $7 \mathrm{Med}$ 1991;324:1430-2.

4 La Spada A, Wilson EM, Lubahn DB, Harding AE, Fischbeck $\mathrm{KH}$. Androgen receptor gene mutations in $\mathrm{X}$-linked spinal and bulbar muscular atrophy. Nature 1991;352:77-8.

5 Williams DB, Windebank AJ. Motor neuron disease (amyotrophic lateral sclerosis). Mayo Clin Proc 1991; 66:54-82.

6 Tandan R, Bradley WG. Amyotrophic lateral sclerosis: Part 2. Etiopathogenesis. Ann Neurol 1985;18:419-31.

7 Rowland LP. Motor neuron diseases and amyotrophic lateral sclerosis: research progress. TINS 1987;10: 393-7.

8 Gajdusek DC. Foci of Motor Neuron Disease in High Incidence in Isolated Populations of East Asia and the Western Pacific. In: Rowland LP, ed. Human motor neuron diseases. New York: Raven Press 1982:363-93.

9 Eisen AA, Hudson AJ. Amyotrophic lateral sclerosis: concepts in pathogenesis and etiology. Can $\mathcal{F}$ Neurol Sci concepts in path

10 Kurland LT, Choi NW, Sayre GP. Implications of incidence and geographic patterns on the classification of amyotrophic lateral sclerosis. In: Norris FH, ed. Motor neuron diseases: research on amyotrophic lateral sclerosis and related disorders. New York and London: Grune and Stratton, 1969:29-49.

11 Kurland LT. Epidemiologic investigations of amyotrophic lateral sclerosis III A genetic interpretation of incidence and geographic distribution. Mayo Clin Proc 1957;32: 449-62.

12 Anonymous. Motor Neurone Disease. Int $\mathcal{f}$ Epidemiol 1972;1:197-8.

13 Bobowick AR, Brody JA. Epidemiology of motor-neuron diseases. N Engl f Med 1973;288:1047-55.

14 Kurtz JF. Epidemiology of amyotrophic lateral sclerosis. In: Rowland P, ed. Human motor neuron diseases. New York: Raven Press, 1982:281-302.

15 Anonymous. What causes motoneuron disease? Lancet 1990;336:1033-5

16 Mulrow $C D$. The medical review article: State of the science. Ann Int Med 1987;106:485-8.

17 Sackett DL, Haynes RB, Guyatt GH, Tugwell P. How to read reviews and economic analysis. Clinical epidemiology. $A$ basic science for clinical medicine, 2nd ed. Boston: Little Brown, 1991:379-91.

18 Goldberg ID, Kurland LT. Mortality in 33 countries from diseases of the nervous system. World Neurol 1963;3: 444-65.

19 Kondo K, Tsubaki T. Changing mortality patterns of motor neuron disease in Japan. $\mathcal{f}$ Neurol Sci 1977 ; 32:411-24.

20 Buckley J, Warlow C, Smith P, Hilton-Jones D, Irvine S, Tew JR. Motor neuron disease in England and Wales 1959-1979. I Neurol Neurosurg Psychiatry 1983;46: 197-205.

21 Martyn CN, Barker DJP, Osmond C. Motoneuron disease and past poliomyelitis in England and Wales. Lancet 1988;1:1319-22.

22 Gunnarsson L-G, Lindberg G, Soderfelt B, Axelson O. The mortality of motor neuron disease in Sweden. Arch Neurol 1990;47:42-6.

23 Lilienfeld DE, Chan E, Ehland J, et al. Rising mortality from motoneuron disease in the USA 1962-84. Lancet 1989;i:710-2.

24 Riggs JE. Longitudinal Gompertzian analysis of amyotrophic lateral sclerosis mortality in the U.S., trophic lateral sclerosis mortality in the U.S., 1977-1986: evidence for an inherently susceptibl

25 Leone ML, Chandra V, Schoenberg BS. Motor neuron disease in the United States, 1971 and 1973-1978: Patterns of mortality and associated conditions at the time of death. Neurology 1987;37:1339-43.

26 Jokelainen $M$. The epidemiology of amyotrophic lateral sclerosis in Finland. A study based on the death certificates of 421 patients. $f$ Neurol Sci 1976;29:55-63.

27 Durrleman S, Alperovitch A. Increasing trend of ALS in France and elsewhere: are the changes real? Neurology 1989;39:768-73.

28 Bharucha NE, Schoenberg BS, Raven RH, Pickle LW, Byar DP, Mason TJ. Geographic distribution of motor neuron disease and correlation with possible etiologic factors. Neurology 1983;33:911-5.

29 Flaten TP. Rising mortality from motoneuron disease. Lancet 1989;i:1018-9.

30 Buncher CR, White M, Moomaw CJ. Amyotrophic lateral 
sclerosis rates in Ohio, 1960-1986. In: Rose FC, Norris FH, eds. Amyotrophic lateral sclerosis. New advances in toxicology and epidemiology. London: Smith-Gordon, 1990:7-10.

31 Vemireddi NK, Crevoiserat CA Jr. Amyotrophic latera sclerosis in Cancer (error in published title, should read "Kansas" not Cancer). $\mathcal{f}$ Miss State Med Assoc 1978;19:201-4.

32 Bale GS. Amyotrohic lateral sclerosis in Iowa. 7 Chronic Dis 1975;28:305-10.

33 Juergens SM, Kurland LT, Okazaki H, Mulder DW. ALS in Rochester, Minnesota, 1925-1977. Neurology 1980 30:463-70.

34 Yoshida S, Mulder DW, Kurland LT, Chu CP, Okazaki H. Follow up study on amyotrophic lateral sclerosis in Rochester, Minn., 1925 through 1984. Neuroepidemiology 1986;5:61-70.

35 Kahana E, Zilber N. Changes in the incidence of amyotrophic lateral sclerosis in Israel. Arch Neurol 1984; 4:157-60.

36 Kahana E, Alter M, Feldman S. Amyotrophic lateral sclerosis: a population study. $\mathcal{f}$ Neurol 1976 212:205-13.

37 Rosati G, Pinna L, Granieri E, et al. Studies on epidemiological, clinical, and etiological aspects of ALS disease in logical, clinical, and etiological aspects of ALS disease in 55:231-44.

38 Forsgren L, Almay BG, Holmgren G, Wall S. Epidemiology of motor neuron disease in northern Sweden. Acto Neurol Scand 1983;68:20-9.

39 Gunnarsson LG, Palm R. Motor neuron disease and heavy manual labour: an epidemiologic survey of Varmland County, Sweden. Neuroepidemiology 1984;3:195-206.

40 Hojer-Pedersen E, Christensen PB, Jensen NB. Incidence and prevalence of motor neuron disease in two Danish counties. Neuroepidemiology 1989;8:151-9.

41 Murros K, Fogelholm R. Amyotrophic lateral sclerosis in Middle-Finland: an epidemiological study. Acta Neurol Scand 1983;67:41-7.

42 Mitchell JD, Gibson HN, Gatrell A. Amyotrophic latera sclerosis in Lancashire and South Cumbria, England, 1976-1986. A geographical study. Arch Neurol 1990 47:875-80.

43 Hudson AJ, Davenport A, Hader WJ. The incidence of amyotrophic lateral sclerosis in southwestern Ontario, Canada. Neurology 1986;36:1524-8.

44 Matsumoto N, Worth RM, Kurland LT, Okazaki H. Epidemiologic study of amyotrophic lateral sclerosis in Hawaii. Identification of high incidence among Filipino men. Neurology 1972;22:934-40.

45 Juvarra G, Bettoni L, Bortone E, Garavelli A, Montanari E, Rocca M. Amyotrophic lateral sclerosis in the province of Parma, Italy: a clinical and epidemiological province of Parma, Italy: a clinical and epidemiological
study in the period 1960-1980. Ital f Neurol Sci study in the

46 Olivares L, Esteban ES, Alter M. Mexican "resistance" to amyotrophic lateral sclerosis. Arch Neurol 1972;27: 397-402

47 Granieri E, Rosati G, Tola R, Pinna L, Paolino E, D'Agostini G. Amyotrophic lateral sclerosis frequency in Italy. Incidence and prevalence in the province of Ferrara. Acta Neurol (Napoli) 1981;36:549-57.

48 Granieri E, Carreras M, Tola $R$, et al. Motor neuron disease in the province of Ferrara, Italy, in 1964-1982. Neurology 1988;38:1604-8.

49 Zack MM, Levitt LP, Schoenberg B. Motor neuron disease in Lehigh county, Pennsylvania: An epidemiologic study. $\Im$ Chron Dis 1977;30:813-8.

50 Leone M, Chio A, Mortara P, Rosso MG, Schiffer D. Motor neuron disease in the Province of Turin, Italy, 1971-1980. Acta Neurol Scand 1983;68:316-27.

51 Murray TJ, Cameron J, Heffernan LP, et al. Amyotrophic lateral sclerosis in Nova Scotia. Adv Exp Med Bio 1987;209:345-9.

52 Radhakrishnan K, Ashok PP, Sridharan R, Mousa ME. Descriptive epidemiology of motor neuron disease in Benghazi, Libya. Neuroepidemiology 1986;5:47-54.

53 Qizilbash N, Bates D. Incidence of motor neurone disease in the northern region. $\mathcal{F}$ Epi Comm Health 1987;41: 18-20.

54 Scarpa M, Colombo A, Panzetti P, Sorgato P. Epidemiology of amyotrophic lateral sclerosis in the province of Modena, Italy. Influence of environmental exposure to lead. Acta Neurol Scand 1988;77:456-60.

55 Cendrowski W, Wender M, Owsianowski M. Analyse epidemilogique de la sclerose laterale amyotrophique sur le territoire de la Grande-Polonge (with English abstract). Acta Neurol Scand 1970;46:609-17.

56 Giagheddu M, Pugaioni G, Masala C, et al. Epidemiologic study of amyotrophic lateral sclerosis in Sardinia, Italy. Acta Neurol Scand 1983;68:394-404.

57 Holloway SM, Mitchell JD. Motor neurone disease in the Lothian Region of Scotland 1961-81. F Epi Comm Health 1986;40:344-50.

58 Bracco L Antuono P, Amaducci L. Study of epidemiological and etiological factors of amyotrophic lateral sclerosis in the province of Florence, Italy. Acta Neurol Scand 1979;60:112-4.

59 Holloway SM, Emery AEH. The epidemiology of motor neuron disease in Scotland. Muscle Nerve 1982;5:131-3.

60 Salemi G, Fierro B, Arcara A, Cassata M, Castiglione MG Savettieri G. Amyotrophic lateral sclerosis in Palermo, Italy: an elidemiological study. Ital f Neurol Sci 1989 10:505-9.
61 Lopez-Vega JM, Calleja J, Combarros O, Polo JM, Berciano J. Motor neuron disease in Cantabria. Acta Neurol Scand 1988;77:1-5.

62 De Domenico P, Malara CE, Marabello L, et al. Amyotrophic lateral sclerosis: An epidemiological study in the province of Messina, Italy, 1976-1985. Neuroepidemiology 1988;7:152-8.

63 Chazot F, Vallat JM, Hugon J, Lubeau M, Dumas M. Amyotrophic lateral sclerosis in Limousin (Limoges area, France). Neuroepidemiology 1986;5:39-46.

64 Norris FH, Denys EH, Sang K, Mukai E. The natural history of ALS in a specified population, with comments on risk factors, prognosis and symptomatic treatments. on risk factors, prognosis and symptom

65 Marco R, Rivera-Reyes L. Motor neuron disease in Puerto Rico: A study of 76 cases. Bol Asoc Med P R 1983;75: $400-2$.

66 Hoffman PM, Brody JA. The reliability of death certificate reporting for amyotrophic lateral sclerosis. $\mathcal{f}$ Chronic Dis 1971;24:5-8.

67 O'Malley F, Dean G, Elian M. Multiple sclerosis and motor neurone disease: survival and how certified after death. $\mathcal{F}$ Epidemiol Community Health 1987;41:14-7.

68 Gardner MJ, Altman DG. Statistics with confidenceconfidence intervals and statistical guidelines. London: BMF, 1989.

69 Paolino E, Granieri E, Tola MR, Rosati G. Conjugal amyotrophic lateral sclerosis. Ann Neurol 1983;14:699.

70 Chad D, Mitsumoto H, Adelman LS, Bradley WG, Munsat TL, Zieper I. Conjugal motor neuron disease. Neurology 1982;32:306-7.

71 Sanders $M$. Clustering of amyotrophic lateral sclerosis [letter]. $\mathcal{F} A M A$ 1980;244:435.

72 Hyser CL, Kissel JT, Mendell JR. Three cases of amyotrophic lateral sclerosis in a common occupational environment. F Neurol 1987;234:443-4.

73 Hochberg FH, Bryan JA, Whelan MA. Letter: Clustering of amyotrophic lateral sclerosis. Lancet 1974;1:34.

74 Melmed C, Krieger C. A cluster of amyotrophic lateral sclerosis. Arch Neurol 1982;39:595-6.

75 Norris FH. Four northern California amyotrophic lateral sclerosis clusters. In: Rose FC, Norris FH, eds. Amytrophic lateral sclerosis. New advances in toxicology and epidemiology. London: Smith-Gordon, 1990:19-21.

76 Gallagher JP. ALS [letter]. South Med $\mathcal{f}$ 1988;81:417.

77 Jokelainen M, Wikstrom J, Palo J. Effect of birthplace on the development of amyotrophic lateral sclerosis and multiple sclerosis. A study among Finnish war evacuees. Acta Neurol Scand 1979;60:283-8.

78 Kilness AW, Hochberg FH. Amyotrophic lateral sclerosis in a high selenium environment. $\mathcal{J} A M A$ 1977;237: 2843-4

79 Hawkes $\mathrm{CH}$, Fox AJ. Motor neurone disease in leather workers [letter]. Lancet 1981;i:507.

80 Abarbanel JM, Herishanu Y, Frisher S. Motor neuron disease in textile factory workers. Isr $\mathcal{F}$ Med Sci 1985;21: 924-5.

81 Sienko DG, Davis JP, Taylor JA, Brooks BR. Amyotrophic lateral sclerosis. A case-control study following detection of a cluster in a small Wisconsin community. Arch Neurol $1990 ; 47: 38-41$.

82 Garruto RM, Gajdusek DC, Chen M. Amyotrophic lateral sclerosis and parkinsonism-dementia among Filipino migrants to Guam. Ann Neurol 1981;10:341-50

83 Jokelainen $M$. Amyotrophic lateral sclerosis in Finland. I: An epidemiologic study. Acta Neurol Scand 1977;56: 185-93.

84 Armon C, Daube JR, O'Brien PC, Kurland LT, Mulder DW. When is a an apparent excess of neurologic cases epidemiologically significant? Neurology 1991;41: 1713-18.

85 Martyn CN. Poliovirus and motor neuron disease. 7 Neurol 1990;237:336-8.

86 Kennedy PGE. On the possible role of viruses in the aetiology of motor neurone disease: a review. 7 Royal Soc Med 1990;83:784-7.

87 Dalakas MC, Edler G, Hallett M, et al. A long-term followup study of patients with post-poliomyelitis neuromusup study of patients with post-poliomyelitis neurom

88 Brody JA, Stanhope JM, Kurland LT. Patterns of amyotrophic lateral sclerosis and parkinsonism-dementia on trophic lateral sclerosis and parkinsonism-dem
Guam. Contem $p$ Neurol Ser 1975;12:45-70.

89 Kurland LT. Geographic isolates: their role in neuroepidemiology. Adv Neurol 1978;19:69-82.

90 Gajdusek DC. Urgent opportunistic observations: the study of changing, transient and disappearing phenomena of medical interest in disrupted primitive human communities. Ciba Found Symp 1977;49:69-94

91 Gajdusek DC, Salazar AM. Amyotrophic lateral sclerosis and parkinsonian syndromes in high incidence among the Auyu and Jakai people of West New Guinea. Neurology 1982;32:107-26.

92 Brody JA, Hirano A, Scott RM. Recent neuropathologic observations in amyotrophic lateral sclerosis and parkinsonism dementia of Guam. Neurology 1971;21: 528-36.

93 Rodgers-Johnson P, Garruto RM, Yanagihara R, Chen KM, Gajdusek DC, Gibbs CJ, Jr. Amyotrophic lateral sclerosis and parkinsonism-dementia on Guam: a 30
year evaluation of clinical and neuropathologic trends. year evaluation of clinical

94 Reed DM, Torres JM, Brody JA. Amyotrophic lateral sclerosis and parkinsonism-dementia on Guam, Epidemiol 1975;101:302-10. 
95 Kurland LT, Molgaard CA. Guamanian ALS: hereditary or acquired? Adv Neurol 1982;36:165-71.

96 Hoffman PM, Robbins DS, Gibbs CJ, Jr., Gajdusek DC, Garruto RM, Terasaki OI. Histocompatibility antigens in amyotrophic lateral sclerosis and parkinsonism-dementia on Guam [letter]. Lancet 1977;2:717.

97 Yanagihara RT, Garruto RM, Gajdusek DC. Epidemiological surveillance of amyotrophic lateral sclerosis and logical surveillance of amyotrophic lateral sclerosis and parkinsonism-dementia in the Commonwealth of the

98 Reed D, Labarthe D, Chen RM, Stallones R. A cohort study of amyotrophic lateral scerlosis and parkinsonismdementia on Guam and Rota. Am $\mathcal{F}$ Epidemiol 1987; 125:92-100.

99 Reed DM, Brody JA. Amyotrophic lateral sclerosis and parkinsonism-dementia on Guam, 1945-1972. I. Descriptive epidemiology. Am $\mathcal{f}$ Epidemiol 1975;101: 287-301

100 Stanhope JM, Brody JA, Morris CE. Epidemiologic features of amyotropic lateral sclerosis and parkinsonism-dementia in Guam, Mariana Islands. Int 7 Epidemiol 1972;1:199-210.

101 Garruto RM, Yanagihara R, Gajdusek DC. Disappearance of high-incidence amyotrophic lateral sclerosis and parkinsonism-dementia on Guam. Neurology 1985;35: 193-8.

102 Lavine L, Steele JC, Wolfe N, et al. Amyotrophic lateral sclerosis/parkinsonism-dementia complex in southern Guam: is it disappearing? Adv Neurol 1991;56:271-85.

103 Brody JA, Edgar AH, Gillespie MM. Amyotrophic lateral sclerosis. No increase among US construction workers in Guam. $\mathscr{F} A M A$ 1978;240:551-60

104 Eldridge R, Ryan E, Rosario J, Brody JA. Amyotrophic lateral sclerosis and parkinsonism dementia in a migrant population from Guam. Neurology 1969;19:1029-37.

105 Garruto RM, Gajdusek C, Chen KM. Amyotrophic lateral sclerosis among Chamorro migrants from Guam. Ann Neurol 1980;8:612-9.

106 Gibbs CJ Jr, Gajdusek DC. Amyotrophic lateral sclerosis, Parkinsons disease, and the amyotrophic lateral scleroParkinsons disease, and the amyotrophic lateral sclerosis-Parkinsonism-dementia complex on Guam: a review
and summary of attempts to demonstrate infection as the and summary of attempts to demonstrate infectio
aetiology. $\mathcal{F}$ Clin Pathol (Suppl) 1972;6:132-40.

107 Spencer PS. Linking cycad to the etiology of Western Pacific amyotrophic lateral sclerosis. In: Rose FC, Norris FH, eds. Amyotrophic lateral sclerosis. New advances in toxicology and epidemiology. London: SmithGordon, 1990:29-34.

108 Spencer PS, Nunn PB, Hugon J, Ludolph A, Roy DN. Motorneurone disease on Guam: possible role of a food neurotoxin [letter]. Lancet 1986;1:965.

109 Spencer PS, Nunn PB, Hugon J, et al. Guam amyotrophic lateral sclerosis-parkinsonian-dementia linked to a plant excitant neurotoxin. Science 1987;237:517-22.

110 Garruto RM, Shankar SK, Yanagihara R, Salazar AM, Amyx HL, Gajdusek DC. Low-calcium, high-aluminum Amyx HL, Gajdusek DC. Low-calcium, high-aluminum diet-induced motor neuron pathology in cynom
monkeys. Acta Neuropathol (Berl) 1989;78:210-9.

111 Duncan MW, Steele JC, Kopin IJ, Markey SP. 2-Amino3-(methylamino)-propanoic acid (BMAA) in cycad flour: an unlikely cause of amyotrophic lateral sclerosis and parkinsonism-dementia of Guam. Neurology 1990;40:767-72.

112 Steele JC, Quinata-Guzman T. The Chamorro diet: an unlikely cause of neurofibrillary degeneration on Guam. In: Rose FC, Norris FH, eds. Amyotrophic lateral sclerosis. New advances in toxicology and epidemiology. London: Smith-Gordon, 1990:71-8.

113 Yanagihara R, Garruto RM, Gajdusek DC, et al. Calcium and vitamin $D$ metabolism in Guamanian Chamorros with amyotrophic lateral sclerosis and parkinsonismwith amyotrophic lateral sclerosis

114 Yase Y. The basic process of amyotrophic lateral sclerosis as reflected in Kii peninsula and Guam. In: den Hartog reflected in Kii peninsula and Guam. In: den Hartog. Jager WA, Bruyn GW, Heijstee APJ, eds. Neurology-Proc
11 th World Congress of Neurology. Amsterdam: Excerpta 11th World Congress of

115 Garruto RM, Swyt C, Yanagihara R, Fiori CE, Gajdusek DC. Intraneuronal co-localization of silicon with calcium and aluminum in amyotrophic lateral sclerosis and parkinsonism with dementia of Guam (letter). $N$ Engl $\mathcal{F}$ Med 1986;315:711-2.

116 Amyotrophic lateral sclerosis. In: Rose FC, Norris FH, eds. New advances in toxicology and epidemiology. London: Smith-Gordon, 1990

$117 \mathrm{Li} \mathrm{T}-\mathrm{M}$, Swash M, Alberman E, Day SJ. Diagnosis of motor neuron disease by neurologists: a study in three countries. I Neurol Neurosurg Psychiatry 1991;

118 Brownell B, Oppenheimer DR, Hughes JT. The central nervous system in motor neurone disease. $f$ Neurol Neurosurg Psychiatry 1970;33:338-57.

119 Mulder DW, Howard FM Jr. Patient resistance and prognosis in amyotrophic lateral sclerosis. Mayo Clin Proc 1976;51:537-41.

120 Gallagher JP, Talbert OR. Motor neuron disease after electric shock. Acta Neurol Scand 1990;83:79-82.

121 Younger DS, Chou S, Hays AP, et al. Primary lateral sclerosis. A clinical diagnosis reemerges. Arch Neurol 1988;45:1304-7

122 Gastaut JL, Michel B, Figarella-Branger D, SommaMauvais $\mathrm{H}$. Chronic progressive spinobulbar spasticity. A rare form of primary lateral-sclerosis. Arch Neurol 1988;45:509-13.

123 Christensen PB, Hojer-Pedersen E, Jensen NB. Survival of patients with amyotrophic lateral sclerosis in 2 Danish counties. Neurology 1990;40:600-4.

124 Vejiajiva A, Foster JB, Miller H. Motor neuron disease. A clinical study. $\mathcal{F}$ Neurol $S c i$ 1967;4:299-314

$125 \mathrm{Li}$ Ting-Ming, Alberman E, Swash M. Clinical features and associations of 560 cases of motor neuron disease. $\mathcal{f}$ Neurol Neurosurg Psychiatry 1990;53:1043-5.

126 Chancellor AM, Swingler RJ, Fraser H, Warlow CP. The Scottish motor neuron disease register: A prospective study of adult onset motor neuron disease in Scotland. Methodology, demography and clinical features of incident cases in 1989. F Neurol Neurosurg Psychiatry 1992;55:536-51

127 Dorsen M, Ehni G. Cervical spondylotic radiculopathy producing motor manifestations mimicking primary muscular atrophy. Neurosurgery 1979;5:427-31.

128 Sadowsky CH, Sachs E, Ochoa J. Postradiation motor neuron syndrome. Arch Neurol 1976;33:786-7.

129 Argov Z, Navon R. Clinical and genetic variations in the syndrome of adult GM2 gangliosidosis resulting from hexosaminadase A deficiency. Ann Neurol 1984;16:

$14-20$.
130 Mitsumoto H, Sliman RJ, Schafer IA, Sternick CS, Wilbourn A, Horwitz SJ. Motor neuron disease and adult hexosaminadase $A$ deficiency in two families: evidence for multisystem degeneration. Ann Neurol 1985;17:378-84.

131 Moser HW, Naidu S. The Adrenoleukodystrophies. CRC crit rev neurobiol 1987;3:29-88.

132 Mulder DW, Bastron JA, Lambert EH. Hyperinsulin neuronopathy. Neurology 1956;6:627-35.

133 Fisher M, Mateer JE, Ullrich I, Gutrecht JA. Pyramidal tract deficits and polyneuropathy in hyperthyroidism, combination clinically mimicking amyotrophic lateral sclerosis. Am $\mathcal{F}$ Med 1985;78:1041-4.

134 Rosati G, Govoni E, Aiello I, Granieri E, Tola R, Bragaglia MM. Hyperthyroidism as a precipitating factor of amyotrophic lateral sclerosis: a case report. Acta Neurol (Napoli) 1980;35:166-72.

135 Patten BM, Engel WK. Phosphate and parathyroid disorders associated with the syndrome of amyotrophic orders associated with the syndrome of am
lateral sclerosis. Adv Neurol 1982;36:181-200.

136 Pestronk A, Cornblath DR, Ilyas AA, et al. A treatable multifocal motor neuropathy with antibodies to GM1 ganglioside. Ann Neurol 1988;24:73-8.

137 Krarup C, Stewart JD, Sumner AJ, Pestronk A, Lipton SA. A syndrome of asymmetric limb weakness with motor conduction block. Neurology 1990;40:118-27.

138 Younger DS, Rowland LP, Latov N, et al. Motor neuron disease and amyotrophic lateral sclerosis: relation of high CSF protein content to paraproteinemia and clinical syndromes. Neurology 1990;40:595-9.

139 Younger DS, Rowland LP, Latov N, et al. Lymphoma, motor neuron diseases, and amyotrophic lateral sclerosis. Ann Neurol 1991;29:78-86.

140 Buchanan DS, Malamud N. Motor neuron disease with renal cell carcinoma and postoperative neurologic remission. Neurology 1973;23:891-4.

141 Preston DC. Paraneoplastic motor neuron disease [letter]. Neurology 1990;40:1638.

142 Mitchell DM, Olczac SA. Remission of a syndrome indistinguishable from motor neurone disease after resection of a bronchial carcinoma. $B M \mathcal{F}$ 1979; 279:176-7.

143 Anonomyous. Missed foramen-magnum tumours. Lancet 1973;ii:1482.

144 Campbell AM, Williams ER, Pearce J. Late motor neuron degeneration following poliomyelitis. Neurology 1969; 19:1101-6.

145 Sonies BC, Dalakas MC. Dysphagia in patients with the post-polio syndrome. $N$ Engl $f$ Med 1991;324:1162-7.

146 Dalakas MC, Pezeshkpour GH. Neuromuscular diseases associated with human immunodeficiency virus. Ann Neurol 1988;23 (suppl):S38-48.

147 Hoffman PM, Festoff BW, Giron IT, Hollenbeck LC Garruto RM, Ruscetti FW. Isolation of LAV/HTLV-III from a patient with amyotrophic lateral sclerosis. $N$ Engl f Med 1985;313:324-5.

148 Datta A, Dasadhikary C, Ghosh S. Syphilitic amyotrophy. f Indian Med Assoc 1966;47:287-90.

149 Martin JP. Amyotrophic meningo-myelitis (spinal progressive muscular atrophy of syphilitic origin). Brain 1925;48:153-82.

150 Kahn P. Cysticercosis of the central nervous system with amyotrophic lateral sclerosis: case report and review of the literature. $f$ Neurol Neurosurg Psychiatry 1972:35: 81-7.

151 Kuroda Y, Sugihara H. Autopsy report of HTLV-I-associated myelopathy presenting with ALS-like manifestaciated myelopathy presenting with A
tions. $\mathcal{f}$ Neurol $S c i$ 1991;106:199-205.

152 Tan SV, Pye IF. Postradiation motor neurone syndrome of the upper cervical region-a manifestation of the comthe upper cervical region-a manifestation of the combined effect of cranial irradiation and intrathecal chem

153 Boothby JA, Dejesus PV, Rowland LP. Reversible forms of motor neuron disease. 1974;31:18-23.

154 Adams CR, Ziegler DK, Lin JT. Mercury intoxication simulating amyotrophic lateral sclerosis. $\mathcal{F A M A} 1983$; 250:642-3.

155 Mitchell JD. Trace elements, neurological disease and amyotrophic lateral sclerosis. In: Chazot G, ed. Current trends in trace elements research. London: Smith-Gordon. 1989:116-24.

156 Mitchell JD, Pentland B, East BW, Harris IA, Jackson MJ. 
Trace elements and free radicals in motor neurone disease (amyotrophic lateral sclerosis). In: Rice-Evans C, ed. Free radicals, cell damage and disease. London: Richelieu Press, 1986:263-72.

157 Patten BM, Brown S. Amyotrophic lateral sclerosis associated with aluminium intoxication. In: Rose FC, Norris FH, eds. Amyotrophic lateral sclerosis. New advances in toxicology and epidemiology. London: Smith-Gordon, toxicology and

158 Hugon J, Ludolph AC, Gimenez-Roldan S, Hague A, Spencer PS. Electrophysiological evaluation of human lathyrism-results in Bangladesh and Spain. In: Rose FC Norris FH, eds. Amyotrophic lateral sclerosis. New advan ces in toxicology and epidemiology. London: Smith-Gordon, 1990:49-56.

159 Teitelbaum JS, Zatorre RJ, Carpenter S, et al. Neurological sequelae of domoic acid intoxication due to the ingestion of contaminated mussels. $N$ Engl $f$ Med 1990; 322:1781-7.

160 Pall HS, Williams AC, Waring R, Elias E. Motorneurone disease as manifestation of pesticide toxicity [letter]. Lancet 1987;ii: 685 .

161 Leys D, Petit H. Clinical signs of amyotrophic lateral sclerosis developing after polyradiculoneuropathy assosclerosis developing after polyradiculoneuropathy
ciated with amitriptyline. $B M 7$ 1990;300:614.

162 Behan PO, Bakheit AM. Association of amyotrophic lateral sclerosis, Hoigne's syndrome and residence in Guam. $\mathcal{F}$
senan

163 Ghatak NR, Hirano A, Zimmerman HM. Rheumatoid arthritis with arteritis and neuropathy masking amyotrophic lateral sclerosis. Rinsho Shinkeigaku 1972;12
401-10.

164 Mathe JF, Fève JR, Labat JJ, De-Kersaint Gilly-A, Potagas C, Dubois C. Ischémie de la corne antérieure de la moelle [English abst]. Rev Neurol (Paris) 1989; 145:60-4.

165 Shepherd Fleet W, Watson RT. From benign fasiculations and cramps to motor neuron disease. Neurology 1986; 36:997-8

166 Rafalowska J, Wasowicz B. Syringomyelia simulating amyotrophic lateral sclerosis. Pol Med f 1968;7:1214-8.

167 Korosue K, Shibasaki H, Kuroiwa Y, et al. Cyst of the conus medullaris manifesting amyotrophic lateral sclerosis syndrome. Folia Psychiat Neurol fpn 1981; 35:507-10.

168 Rosenberg RN. Amyotrophy in Multisystem Genetic Diseases. In: Rowland LP, ed. Human motor neuron diseases. New York: Raven Press, 1982:149-57.

169 Tyler HR. Nonfamilial amyotrophy with dementia or multisystem degeneration and other neurological disorders. Adv Neurol 1982;36:173-80.

170 Rosenberg RN, Fowler HL. Autosomal dominant motor system disease of the Portuguese: A review. Neurology 1981;31:1125-6.

171 Hudson AJ. Amyotrophic lateral sclerosis and its associa tion with dementia, parkinsonism and other neurological tion with dementia, parkinsonism and other ne

172 Oryema J, Ashby P, Spiegel S. Monomelic atrophy. Can $\mathcal{f}$ Neurol Sci 1990;17:124-30.

173 Olney RK, Aminoff MJ, So YT. Clinical and electrodiagnostic features of $\mathrm{X}$-linked bulbospinal neuronopathy. Neurology 1991;41:823-8.

\section{Neurological stamp}

\section{Edmund Halley (1656-1742)}

Edmund Halley, best known for his contributions to astronomy and particularly the calculation of the orbit of a comet, later named after him, was one of the first medical statisticians. In 1693, more than a century after the first modern life insurance policy (1583) was issued in England, he created a true actuarial table when he published the mortality tables for the city of Breslau, "to ascertain the prices of annuities upon lives." This was one of the first attempts to relate mortality and age in a population and influenced the further development of such tables in life insurance.

He was a friend of Isaac Newton and discussed with him the law of force under which planets move in elliptical orbits with the sun in one focus. As a result he persuaded Newton to prepare and publish his masterpiece Principia, which Halley himself financed. A man of remarkable versatility, working to the threshold of extreme old age he also wrote poetry, propounded a theory to account for changes in the earth's magnetism, was the first to use the barometer to measure heights, made important contributions to gunnery and ballistics, improved the diving bell and gave a critical discussion of the time and landing of Julius Caesar in Britain.

This stamp of the British Antarctic Territory was one of many issued in 1986 commemorating the appearance of Halley's Comet. (Stanley Gibbons 147, Scott 129).

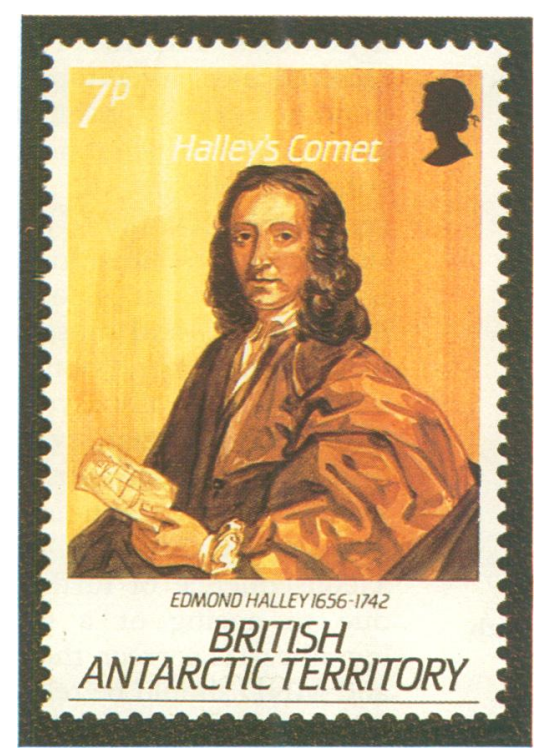

